\title{
Mycobacterium stomatepiae sp. nov., a slowly growing, non-chromogenic species isolated from fish
}

Correspondence

Fazel Pourahmad

fp4@stir.ac.uk
Fazel Pourahmad, ${ }^{1,2}$ Fabio Cervellione, ${ }^{1,3}$ Kim D. Thompson, ${ }^{1}$ John B. Taggart, ${ }^{1}$ Alexandra Adams ${ }^{1}$ and Randolph H. Richards ${ }^{1}$

\author{
${ }^{1}$ Institute of Aquaculture, University of Stirling, Stirling FK9 4LA, UK \\ ${ }^{2}$ School of Veterinary Medicine, Ilam University, PO Box 69315-516, Ilam, Iran \\ ${ }^{3}$ Skretting, Frazione San Zeno, 37060 Mozzecane, Italy
}

\begin{abstract}
Slowly growing, non-chromogenic mycobacteria were isolated from striped barombi mbo cichlids (Stomatepia mariae) maintained at the London Zoo Aquarium, UK. The isolates could be differentiated from other slowly growing, non-pigmented mycobacteria by a combination of phenotypic features including their inability to grow at $37{ }^{\circ} \mathrm{C}$, positive tests for heat-stable catalase, tellurite reduction and arylsulfatase activity, and the absence of urease activity, Tween 80 hydrolysis, nitrate reductase, iron uptake and semiquantitative catalase. The almost full-length $16 \mathrm{~S}$ rRNA gene sequence, together with partial sequences from the $65 \mathrm{kDa}$ heat-shock protein ( $h s p 65$ ) and the $\beta$-subunit of the bacterial RNA polymerase (rpoB) genes and the 16S-23S internal transcribed spacer 1 (ITS 1) region were identical for all three novel strains, but distinct from those of all known mycobacterial species. Phylogenetic analysis based on 16S rRNA gene sequences placed the novel isolates within the slowly growing mycobacteria group in close proximity to Mycobacterium florentinum. Based on genotypic and phenotypic findings, it is proposed that these isolates represent a novel species of the genus Mycobacterium, for which the name Mycobacterium stomatepiae sp. nov. is proposed with strain ${\mathrm{T} 11^{\top}}^{\top}\left(=\mathrm{DSM} 45059^{\top}=\mathrm{CIP}\right.$ $109275^{\top}=$ NCIMB $14252^{\top}$ ) as the type strain.
\end{abstract}

In the past few years, the occurrence of fish mycobacteriosis has been increasingly reported (Kent et al., 2004; Pate et al., 2005; Sakai et al., 2005; Whipps et al., 2007b). Although three species, Mycobacterium marinum, Mycobacterium fortuitum and Mycobacterium chelonae, have been frequently cited as the main causative agents of infections in fish, several other mycobacterial species, including a number of novel species, have also been associated with mycobacteriosis (Levi et al., 2003; Rhodes et al., 2003, 2005; Whipps et al., 2007a).

The majority of slowly growing mycobacteria contain a long helix 18 at position 430-500 (Escherichia coli 16S rRNA gene sequence numbering) in their 16S rRNA gene, which is absent in rapidly growing mycobacteria (Springer

Abbreviations: ITS, internal transcribed spacer; MSR, M. simiae-related; PRA, PCR-restriction enzyme analysis.

The GenBank/EMBL/DDBJ accession numbers for the 16S rRNA, $h s p 65$ and $r p o B$ gene sequences and ITS 1 region of $M$. stomatepiae sp.

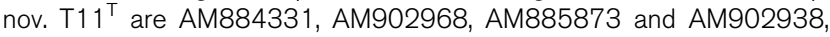
respectively.

Neighbour-joining phylogenetic trees based on hsp65 (Fig. S1) and rрoB (Fig. S2) gene sequences of $M$. stomatepiae sp. nov. and selected mycobacterial species, and the oligonucleotides used for 16S rRNA gene sequencing (Table S1) are available with the online version of this paper. et al., 1996a; Tortoli, 2003). There is a third group, with a short helix 18 (due to a deletion of $12 \mathrm{bp}$ ), and members of this group are also classified as slow growers (Tortoli, 2003). In this group, Mycobacterium simiae, a photochromogenic organism from monkeys, was the first species to be identified (Weiszfeiler et al., 1981). Mycobacterium intermedium (Meier et al., 1993) is another photochromogenic species related to $M$. simiae. Scotochromogenic species of the M. simiae-related (MSR) group consist of Mycobacterium interjectum (Springer et al., 1993), Мycobacterium kubicae (Floyd et al., 2000), Mycobacterium palustre (Torkko et al., 2002), Mycobacterium parascrofulaceum (Turenne et al., 2004a), Mycobacterium parmense (Fanti et al., 2004) and Mycobacterium saskatchewanense (Turenne et al., 2004b). Within the MSR group, there are also non-chromogenic species including Mycobacterium genavense (Böttger et al., 1993), Mycobacterium lentiflavum (Springer et al., 1996b), Mycobacterium triplex (Floyd et al., 1996), Mycobacterium heidelbergense (Haas et al., 1997), Mycobacterium montefiorense (Levi et al., 2003), 'Mycobacterium sherrisii' (Selvarangan et al., 2004) and Mycobacterium florentinum (Tortoli et al., 2005).

Of the MSR species, only M. montefiorense and M. triplex have been isolated from fish (Herbst et al., 2001; Rhodes et al., 
2004). Moreover, isolation of M. simiae from fish has been reported based on biochemical identification (Lansdell et al., 1993). Recently, several MSR organisms have been proposed to be responsible for infections in a number of fish species based on DNA sequences obtained directly from tissue samples (Whipps et al., 2003; Poort et al., 2006). In this context, slowly growing, acid-fast, non-pigmented microorganisms were isolated from kidney and spleen tissue samples of three diseased Stomatepia mariae (striped barombi mbo or nsess; a cichlid fish endemic to Lake Barombi-Mbo, Cameroon). Specimens were collected at different times over a 7 month period. Polyphasic studies employing biochemical tests, whole-cell fatty acid and mycolic acid analysis, and sequencing of the $16 \mathrm{~S} \mathrm{rRNA}, 65 \mathrm{kDa}$ heat-shock protein (hsp65) and polymerase $\beta$-subunit ( $r p o B$ ) genes and the 16S$23 \mathrm{~S}$ internal transcribed spacer 1 (ITS 1 ) region indicated that these isolates represent a single novel species, for which the name Mycobacterium stomatepiae sp. nov. is proposed.

All isolates $(n=3)$ were collected by using an aseptic technique from specimens of Stomatepia mariae held at the London Zoo Aquarium, UK. Isolates $\mathrm{T}_{1} 1^{\mathrm{T}}$ and $\mathrm{T} 3$ were recovered from granulomatous spleen tissue samples and grown on Middlebrook 7H10 medium supplemented with $10 \%$ oleic acid-albumin-glucose-catalase (OADC; Becton Dickinson) and $0.5 \%$ glycerol (Sigma) for 4 weeks at $30{ }^{\circ} \mathrm{C}$ following decontamination with $2 \% \mathrm{NaOH}(\mathrm{w} / \mathrm{v})$ for $15 \mathrm{~min}$. Strain T4 was isolated from kidney tissue, without $\mathrm{NaOH}$ decontamination, using the same conditions as the $\mathrm{T} 11^{\mathrm{T}}$ and $\mathrm{T} 3$ isolates. The spleen and liver of the fish from which strain T4 was recovered were fixed in $10 \%$ buffered formalin. Later, Ziehl-Neelsen staining of tissue sections showed multiple granulomas and a few acid-fast bacilli characteristic of fish mycobacteriosis.

Colony morphology, pigment production when incubated in the dark and following photoinduction, and the ability to grow at temperatures of $15-42{ }^{\circ} \mathrm{C}$ were examined during a 12 week incubation on two different media, Middlebrook 7H10 medium with OADC enrichment and LöwensteinJensen (LJ) medium.

Acid-alcohol-fastness was determined by Ziehl-Neelsen staining. The following biochemical features were investigated: tellurite reduction (tellurite reductase), nitrate reductase, 3 day arylsulfatase, semiquantitative catalase, iron uptake, Tween 80 hydrolysis and urease activity (Kent \& Kubica, 1985). The ability to grow on MacConkey agar without crystal violet and on LJ medium in the presence of sodium chloride (5\%) was also tested (Cooksey et al., 2004).

Whole-cell fatty acid and mycolic acid analyses were performed commercially by the Deutsche Sammlung von Mikroorganismen und Zellkulturen GmbH (DSMZ), Braunschweig, Germany, by GC and HPLC, respectively, as described previously (Butler et al., 1992) using standard Microbial Identification System software (MIDI).

Sequence data were obtained from four distinct regions of the mycobacterial genome. Briefly, DNA was extracted from cultures and, where indicated, from formalin-fixed tissue samples, using NucleoSpin columns (MachereyNagel) following the manufacturer's instructions. PCR amplicons were purified using Qiaquick purification columns (Qiagen) and sequenced in both directions using the original amplicon primers (and internal primers where necessary). Fluorescently labelled templates were generated using a GenomeLab Dye Terminator Cycle Sequencing Quick Start kit (Beckman Coulter) and read on a CEQ8800 automated capillary sequencer (Beckman Coulter). All primer sequences are given in $5^{\prime} \rightarrow 3^{\prime}$ orientation.

PCR amplifications of the 16S rRNA gene (1471 bp) were performed using primers pA (AGAGTTTGATCCTGGCTCAG) and $\mathrm{pH}^{\bullet}$ (AAGGAGGTGATCCAGCCGCA) as described previously (Edwards et al., 1989). Additional internal primers are given in Supplementary Table S1 (available in IJSEM Online). ITS 1 region amplicons (226 bp) were generated using primers Sp1 (ACCTCCTTTCTAAGGAGCACC) and Sp2 (GATGCTCGCAACCACTATCCA) as described previously (Roth et al., 2000). An $r p o B$ gene fragment (360 bp) was amplified using primers RPO5' and RPO3' as described by Lee et al. (2003). Finally, the DNAs extracted from three sources (fresh fish tissue, fixed fish tissue samples and pure cultures of $\mathrm{T} 11^{\mathrm{T}}$, T4 and T3) were subjected to both PCR-restriction enzyme analysis (PRA) and sequence analysis of the $h s p 65$ gene. PRA of the $h s p 65$ gene was performed as described previously (Telenti et al., 1993). Briefly, a 441 bp fragment of the hsp65 gene was amplified by PCR and digested with $B s t \mathrm{EI}$ and HaeIII restriction endonucleases. The restriction fragments were separated by agarose gel electrophoresis and visualized by ethidium bromide staining. The restriction pattern was compared with the published algorithm (Telenti et al., 1993) and with available PRA profiles from PRASITE (http://app.chuv.ch/prasite). The remainder of the PCR product was sequenced using the forward and reverse PCR primers Tb11 (ACCAACGATGGTGTGTCCAT) and Tb12 (CTTGTCGAACCGCATACCCT). Primer Tb11 gave inconsistent sequencing results and was later replaced by primer F927 (GAGGACCCGTACGAGAAGAT; in-house design). Use of this primer, which is $39 \mathrm{bp}$ further along the sequence than primer Tb11, resulted in greatly improved sequence data.

Both forward and reverse sequences were assembled and edited using the SEQMAN II module of LASERGENE v.6 (DNASTAR). The resulting consensus sequences were compared with published nucleotide sequences (in all cases BLASTN analyses were employed; $\mathrm{nr}$ database, default settings; NCBI website, http://www.ncbi.nlm.nih.gov/ blast/Blast.cgi).

Phylogenetic trees were constructed within a group of related mycobacterial species using the neighbour-joining method in MEGA version 3.1 software (Kumar et al., 2004) applying the Kimura two-parameter distance correction model. The tree inferred from the 16S rRNA gene sequences was rooted using Mycobacterium tuberculosis 
NCTC $7416^{\mathrm{T}}$ (GenBank accession no. X58890) as the outgroup. Statistical confidences in tree branches were generated by performing 1000 bootstrap replicates.

Strains $\mathrm{T}_{1} 1^{\mathrm{T}}$ and $\mathrm{T} 3$ were examined with a commercial probe kit (INNO-LiPA Mycobacteria version 2; Innogenetics), a PCR-based reverse hybridization assay targeting the ITS 1 region (Tortoli et al., 2003; Lebrun et al., 2005), following the manufacturer's instructions.

Growth characteristics, acid-fastness and multigene sequencing results were consistent with those of members of the genus Mycobacterium. Colonies were visible after 4 weeks incubation at $30{ }^{\circ} \mathrm{C}$ or 6 weeks at $22{ }^{\circ} \mathrm{C}$ on both Middlebrook 7H10 and LJ media. However, no growth was observed within a 12 week incubation period at 15,37 or $42{ }^{\circ} \mathrm{C}$ on either medium. Colonies grown on Middlebrook $7 \mathrm{H} 10$ agar were smooth, off-white and non-chromogenic. They were negative for nitrate reductase, urease activity, iron uptake, semiquantitative catalase and Tween 80 hydrolysis and positive for heat-stable catalase, tellurite reduction and arylsulfatase activity (Table 1 ). Growth was inhibited on MacConkey agar and on LJ medium supplemented with $5 \% \mathrm{NaCl}$.

The HPLC elution patterns for the three isolates appeared to be identical and fell within the triple-peak cluster that characterizes most MSR organisms (Tortoli et al., 2005). The pattern was similar to that of M. florentinum in that it contained a three-clustered group of peaks emerging later than single peaks. The relative retention time of the main component of the triplet was also very similar in both species (Fig. 1). Major cellular fatty acids of strain $\mathrm{T} 11^{\mathrm{T}}$ were $18: 1 \omega 9 c(50.8 \%)$ and $16: 0(17.6 \%)$; this combina- tion clearly differentiated strain $\mathrm{T} 11^{\mathrm{T}}$ from other closely related species, as shown in Table 2.

The nearly complete $16 \mathrm{~S}$ rRNA gene sequence, consisting of a continuous stretch of $1471 \mathrm{bp}$, corresponding to positions 28-1528 of the E. coli sequence (Brosius et al., 1978), was determined for all isolates. All sequences were identical and contained the characteristic short helix 18 (region B) observed in M. simiae and other slowly growing MSR species. Using BLASTN against sequences from GenBank, EMBL and DDBJ, the closest match was with M. florentinum DSM $44852^{\mathrm{T}}$ (GenBank accession no. AJ616230) with 4 bp mismatches (1467/1471 bp; 2 bp in hypervariable region $\mathrm{A}$ and $2 \mathrm{bp}$ out of hypervariable regions). The phylogenetic tree confirmed the results of sequence analysis (Fig. 2).

All isolates revealed identical ITS 1 sequences. A BLAST search analysis in the GenBank database revealed closest similarity to $M$. lentiflavum ATCC $51985^{\mathrm{T}}$ (GenBank accession no. AF318174), with a $98.4 \%$ match (3 bp differences).

Sequences of the $\operatorname{rpoB}(321 \mathrm{bp})$ gene were identical in all three novel isolates. This sequence was unique; the most closely related sequence was identified in Mycobacterium mageritense CIP $104973^{\mathrm{T}}$ (GenBank accession no. P000479; $91.9 \%$ similarity, corresponding to $26 \mathrm{bp}$ mismatches).

The hsp65 gene of the all novel isolates contained a PCRrestriction fragment length polymorphism pattern that was compatible with that of $M$. triplex. Patterns consisted of three fragments of 145, 130 and 50 bp by BstEII digestion and two fragments of 330 and 115 bp by HaeIII digestion. All of the sequences obtained from DNA extracted from

Table 1. Phenotypic characteristics of $M$. stomatepiae sp. nov. and closely related species

Species: 1, M. stomatepiae sp. nov.; 2, M. florentinum; 3, M. montefiorense; 4, M. simiae; 5, M. genavense; 6, M. lentiflavum; 7, M. triplex; 8, M. heidelbergense; 9, M. intermedium; 10, M. interjectum; 11, 'M. sherrisii'. N, Non-chromogenic; P, photochromogenic; sc, scotochromogenic; s, smooth; -, negative; +, positive; +/-, variable; empty cell, no data available. Data for species other than M. stomatepiae are from Levi et al. (2003), Tortoli et al. (2005) and Tortoli (2006).

\begin{tabular}{|c|c|c|c|c|c|c|c|c|c|c|c|}
\hline Characteristic & 1 & 2 & 3 & 4 & 5 & 6 & 7 & 8 & 9 & 10 & 11 \\
\hline Pigmentation & $\mathrm{N}$ & $\mathrm{N}$ & $\mathrm{N}$ & $\mathrm{P}$ & $\mathrm{N}$ & SC & $\mathrm{N}$ & $\mathrm{N}$ & $\mathrm{P}$ & SC & $\mathrm{N}$ \\
\hline Colony morphology & S & s & & & & s & S & & & S & s \\
\hline Tween 80 hydrolysis & - & - & - & - & - & - & - & + & + & + & - \\
\hline Tellurite reduction & + & + & + & + & - & - & & - & & & \\
\hline Catalase $\left(68{ }^{\circ} \mathrm{C}\right)$ & + & $+1-$ & - & + & + & $+1-$ & + & + & + & + & + \\
\hline Urease & - & + & - & + & + & - & + & + & + & + & + \\
\hline Arylsulfatase & + & - & - & + & - & - & - & + & + & - & - \\
\hline \multicolumn{12}{|l|}{ Growth on/at: } \\
\hline $5 \% \mathrm{NaCl}$ & - & - & - & - & & & - & - & & - & \\
\hline MacConkey agar without crystal violet & - & - & & & & & & & & & \\
\hline $30{ }^{\circ} \mathrm{C}$ & + & + & - & + & + & + & + & + & + & + & + \\
\hline
\end{tabular}




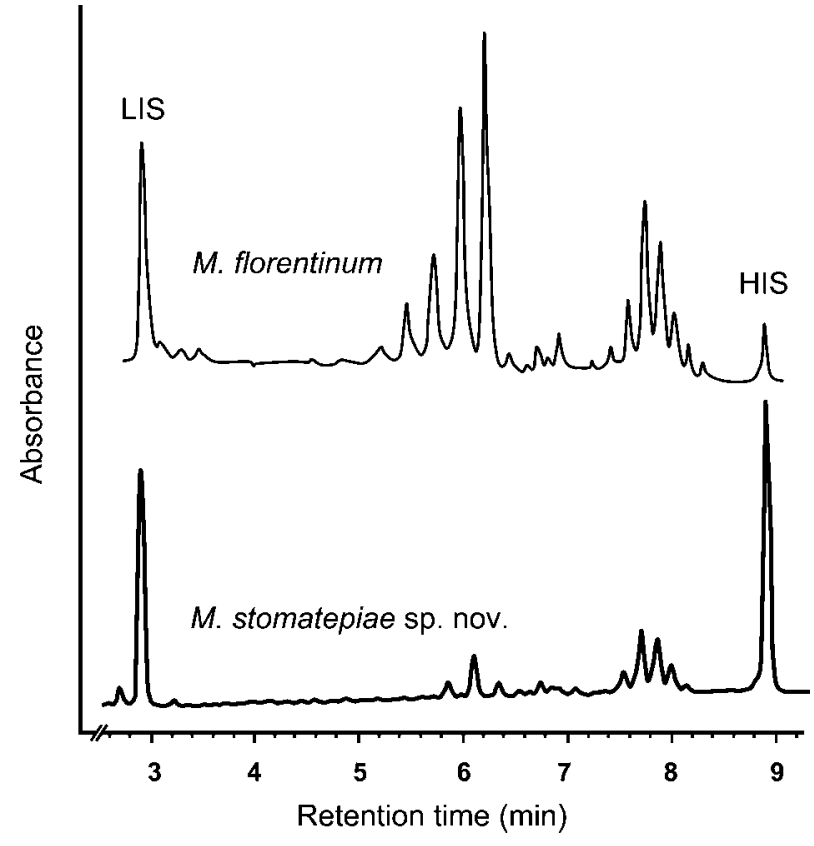

Fig. 1. Mycolic acid HPLC profiles of M. stomatepiae sp. nov. strain $\mathrm{T} 11^{\top}$ and M. florentinum (Tortoli et al., 2005). HIS, Highmolecular-mass internal standard; LIS, low-molecular-mass internal standard.

cultures and fixed and fresh tissues were identical. The sequence of the hypervariable region of the novel isolates (Ringuet et al., 1999) was significantly different from those of other closely related slowly growing species. Phylogenetic analysis of $401 \mathrm{bp}$ of this gene revealed that M. triplex CIP $106108^{\mathrm{T}}$ (GenBank accession no. AF547882) had the highest similarity (98\%; 8 bp mismatches). The neighbour-joining trees based on comparison of $h s p 65$ and $r p o B$ gene sequences are shown in Supplementary Figs S1 and S2, respectively (available in IJSEM Online).

Strains $\mathrm{T} 11^{\mathrm{T}}$ and $\mathrm{T} 3$ were strongly reactive with the Mycobacterium genus-specific probe in the INNO-LiPA kit, whereas they did not hybridize with any of the speciesspecific probes included in the assay.

Evidence suggests that MSR species are difficult to culture in vitro. For example, based on 16S rRNA gene and ITS 1 sequence data from infected fish tissue, Whipps et al. (2003) characterized an MSR organism that was most closely related to $M$. montefiorense (99.2\% $16 \mathrm{~S}$ rRNA gene sequence similarity). Similarly, from analysis of ethanolfixed tissues from both shortfin molly (Poecilia mexicana) and green swordtail (Xiphophorus hellerii), Poort et al. (2006) detected a Mycobacterium species with a 16S rRNA gene sequence that was very similar to that of the proposed novel species described here. However, in both of these investigations, a live bacterium could not be isolated. Moreover, these results strengthen the hypothesis of Levi et al. (2003) who suggested that MSR and Mycobacterium avium-related organisms are common pathogens of aquatic animal environments.

The DNA-DNA hybridization method was not used in this study. The lack of a central database (particularly for mycobacterial species) and inherent technical difficulties in

Table 2. Microbial identification system whole-cell fatty acid analysis of $M$. stomatepiae sp. nov. and closely related species

Taxa: 1, M. stomatepiae sp. nov.; 2, 'M. sherrisii'; 3, M. simiae; 4, M. genavense; 5, M. lentiflavum; 6, M. triplex; 7, M. heidelbergense; 8, M. intermedium; 9, M. interjectum. Data for taxa 2-8 are from Selvarangan et al. (2004). Values given are percentages; empty cells indicate that no data are available.

\begin{tabular}{|c|c|c|c|c|c|c|c|c|c|}
\hline Fatty acid & 1 & 2 & 3 & 4 & 5 & 6 & 7 & 8 & 9 \\
\hline $12: 0$ & & & & & & & 1.0 & 1.2 & \\
\hline $14: 0$ & 4.9 & 7.4 & 8.2 & 8.6 & 6.9 & 8.1 & 5.5 & 6.6 & 5.6 \\
\hline 2-Me-14:0 & & & & & & & 1.3 & 1.5 & \\
\hline $15: 0$ & 0.5 & 0.7 & 0.7 & 0.8 & 0.7 & 0.6 & 0.6 & 0.4 & 1.2 \\
\hline $16: 1 \omega 9 c$ & 9.7 & 2.5 & 2.1 & 0.7 & 7.0 & 2.1 & 1.7 & 0.8 & 4.8 \\
\hline $16: 1 \omega 7 c$ & 0.9 & 1.5 & 1.3 & & & 2.3 & 3.4 & 5.4 & 4.0 \\
\hline $16: 1 \omega 6 c$ & 6.4 & & & 10.2 & 3.8 & 10.5 & 4.6 & 4.4 & \\
\hline $16: 1 \omega 5 c$ & & 2.8 & & & & & 0.5 & 0.6 & \\
\hline $16: 0$ & 17.6 & 37.7 & 41.4 & 35.9 & 31.8 & 32.2 & 43.0 & 44.5 & 23.7 \\
\hline $17: 1 \omega 8 c$ & 0.1 & 0.5 & & & & & & & \\
\hline $17: 0$ & 0.7 & 0.8 & 0.9 & 0.6 & 0.9 & 0.7 & 0.6 & 0.5 & 1.2 \\
\hline $18: 2 \omega 6,9 c$ & 2.4 & & & & & & & & \\
\hline $18: 1 \omega 9 c$ & 50.8 & 30.7 & 27.7 & 31.1 & 34.5 & 28.0 & 22.1 & 21.6 & 23.5 \\
\hline $18: 1 \omega 7 c$ & 1.1 & & & & & & & & \\
\hline $18: 0$ & 2.6 & 3.2 & 5.4 & 2.3 & 4.3 & 3.1 & 5.1 & 4.1 & 7.9 \\
\hline 10-Me-18 (TBSA) & 1.8 & 10.8 & 7.2 & 8.6 & 8.4 & 10.8 & 9.1 & 7.1 & 15.6 \\
\hline $20: 0$ & 0.7 & 1.0 & 1.0 & & 1.1 & 0.7 & 0.7 & 0.5 & 0.4 \\
\hline
\end{tabular}




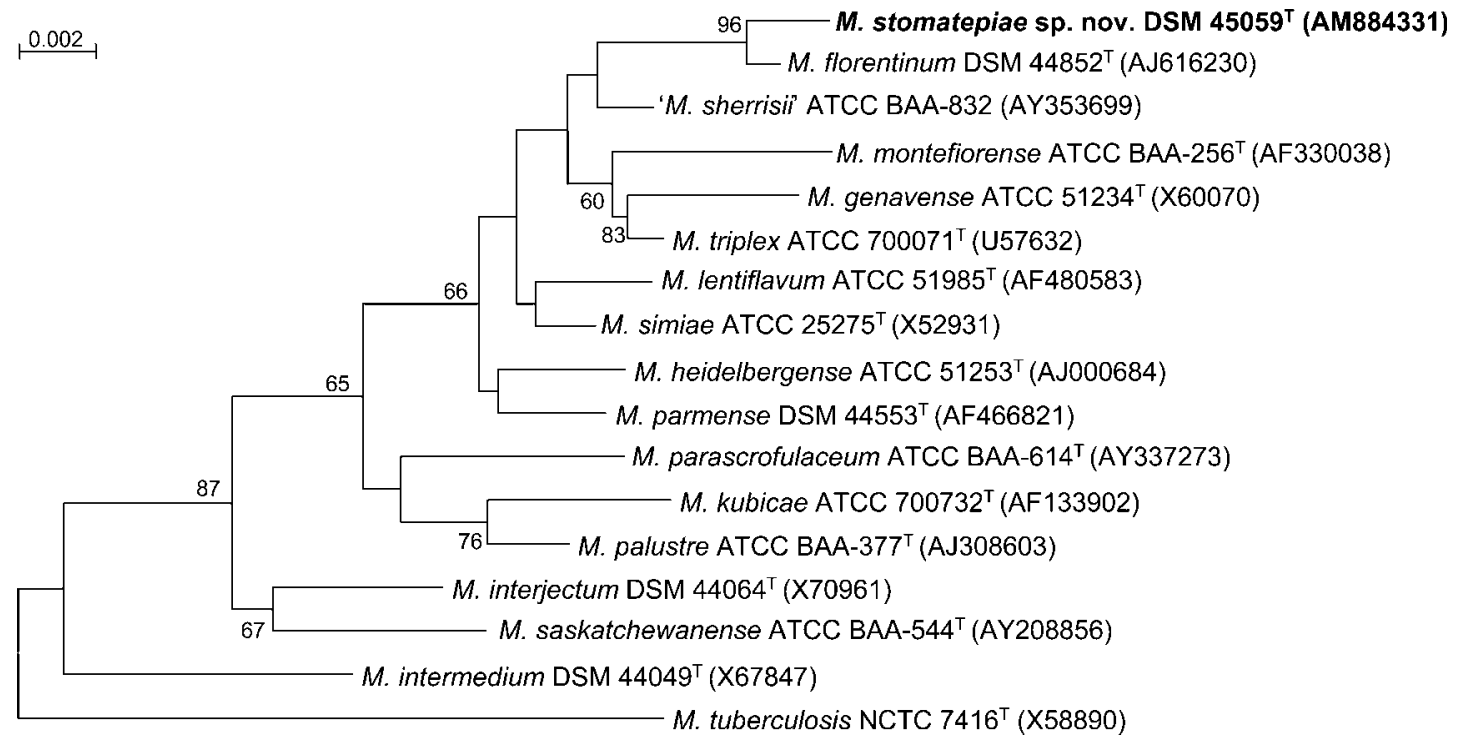

Fig. 2. Neighbour-joining phylogenetic tree based on 16S rRNA gene sequences including mycobacterial species genetically related to M. simiae. M. tuberculosis NCTC $7416^{\top}$ was used as an outgroup. Numbers on the dendrogram are percentages of occurrence in 1000 bootstrapped trees (values $>50 \%$ are shown). Bar, 0.002 substitutions per site.

performing this test to a satisfactory and consistent standard (Short et al., 2005; Adékambi et al., 2006) limit its applicability. However, the application of polyphasic analyses for the formal identification of Mycobacterium species is a valid and well-recognized approach (Adékambi \& Drancourt, 2004; Devulder et al., 2005; Rhodes et al., 2005; Adékambi et al., 2006).

\section{Description of Mycobacterium stomatepiae sp. nov.}

Mycobacterium stomatepiae (sto.ma.tep'i.ae. N.L. gen. n. stomatepiae of Stomatepia, isolated from Stomatepia mari$a e$, the scientific name of the striped barombi mbo cichlid).

Cells are non-chromogenic, slowly growing, acid-fast bacilli. Smooth colonies are produced after 4-6 weeks on Middlebrook $7 \mathrm{H} 10$ medium at $22-30{ }^{\circ} \mathrm{C}$, with optimal growth at $30{ }^{\circ} \mathrm{C}$. No growth occurs at $37^{\circ} \mathrm{C}$ or above. Does not grow on MacConkey agar without crystal violet or on LJ medium with $5 \% \mathrm{NaCl}$. Tests for heat-stable catalase, tellurite reduction and arylsulfatase activity are positive, but those for nitrate reductase, urease activity, iron uptake, semiquantitative catalase and Tween 80 hydrolysis are negative. Partial sequences of the $16 \mathrm{~S}$ rRNA (1471 bp), rpoB (321 bp), hsp65 (401 bp) genes and ITS 1 (183 bp) sequences are substantially different from those of all currently recognized species of the genus Mycobacterium. The fatty acid composition profile is unique and can be used for differentiation from closely related species. Exhibits a mycolic acid profile (HPLC analysis) characterized by a pattern of triple-peak clusters that is typical of MSR species, particularly M. florentinum. Phylogenetic analysis using 16S rRNA gene sequences shows that M. stomatepiae belongs to the slowly growing mycobacteria and is closely related to M. florentinum.
The type strain, $\mathrm{T} 11^{\mathrm{T}}\left(=\mathrm{DSM} 45059^{\mathrm{T}}=\mathrm{CIP} 109275^{\mathrm{T}}=\right.$ NCIMB $14252^{\mathrm{T}}$ ), was isolated from granulomatous lesions in spleen tissue from a striped barombi mbo cichlid.

\section{Acknowledgements}

We are grateful to Dr Enrico Tortoli for his assistance with the interpretation of the HPLC profile. We thank Dr Andrew Routh from the London Zoo Aquarium for providing the fish tissue samples.

\section{References}

Adékambi, T. \& Drancourt, M. (2004). Dissection of phylogenetic relationships among 19 rapidly growing Mycobacterium species by $16 \mathrm{~S}$ rRNA, hsp65, sodA, recA and rpoB gene sequencing. Int J Syst Evol Microbiol 54, 2095-2105.

Adékambi, T., Berger, P., Raoult, D. \& Drancourt, M. (2006). $r p o B$ gene sequence-based characterization of emerging non-tuberculous mycobacteria with descriptions of Mycobacterium bolletii sp. nov., Mycobacterium phocaicum sp. nov. and Mycobacterium aubagnense sp. nov. Int J Syst Evol Microbiol 56, 133-143.

Böttger, E. C., Hirschel, B. \& Coyle, M. B. (1993). Mycobacterium genavense sp. nov. Int J Syst Bacteriol 43, 841-843.

Brosius, J., Palmer, M. L., Kennedy, P. J. \& Noller, H. F. (1978). Complete nucleotide sequence of a $16 \mathrm{~S}$ ribosomal RNA gene from Escherichia coli. Proc Natl Acad Sci U S A 75, 4801-4805.

Butler, W. R., Thibert, L. \& Kilburn, J. O. (1992). Identification of Mycobacterium avium complex strains and some similar species by highperformance liquid chromatography. J Clin Microbiol 30, 2698-2704.

Cooksey, R. C., de Waard, J. H., Yakrus, M. A., Rivera, I., Chopite, M., Toney, S. R., Morlock, G. P. \& Butler, W. R. (2004). Mycobacterium cosmeticum sp. nov., a novel rapidly growing species isolated from a cosmetic infection and from a nail salon. Int J Syst Evol Microbiol 54, 2385-2391. 
Devulder, G., Pérouse de Montclos, M. \& Flandrois, J. P. (2005). A multigene approach to phylogenetic analysis using the genus Mycobacterium as a model. Int J Syst Evol Microbiol 55, 293-302.

Edwards, U., Rogall, T., Blöcker, H., Emde, M. \& Böttger, E. C. (1989). Isolation and direct complete nucleotide determination of entire genes. Characterization of a gene coding for $16 \mathrm{~S}$ ribosomal RNA. Nucleic Acids Res 17, 7843-7853.

Fanti, F., Tortoli, E., Hall, L., Roberts, G. D., Kroppenstedt, R. M., Dodi, I., Conti, S., Polonelli, L. \& Chezzi, C. (2004). Mycobacterium parmense sp. nov. Int J Syst Evol Microbiol 54, 1123-1127.

Floyd, M. M., Guthertz, L. S., Silcox, V. A., Duffey, P. S., Jang, Y., Desmond, E. P., Crawford, J. T. \& Butler, W. R. (1996). Characterization of an SAV organism and proposal of Mycobacterium triplex sp. nov. J Clin Microbiol 34, 2963-2967.

Floyd, M. M., Gross, W. M., Bonato, D. A., Silcox, V. A., Smithwick, R. W., Metchock, B., Crawford, J. T. \& Butler, W. R. (2000). Mycobacterium kubicae sp. nov., a slowly growing, scotochromogenic Mycobacterium. Int J Syst Evol Microbiol 50, 1811-1816.

Haas, W. H., Butler, W. R., Kirschner, P., Plikaytis, B. B., Coyle, M. B., Amthor, B., Steigerwalt, A. G., Brenner, D. J., Salfinger, M. \& other authors (1997). A new agent of mycobacterial lymphadenitis in children: Mycobacterium heidelbergense sp. nov. J Clin Microbiol 35, 3203-3209.

Herbst, L. H., Costa, S. F., Weiss, L. M., Johnson, L. K., Bartell, J., Davis, R., Walsh, M. \& Levi, M. (2001). Granulomatous skin lesions in moray eels caused by a novel Mycobacterium species related to Mycobacterium triplex. Infect Immun 69, 4639-4646.

Kent, P. T. \& Kubica, G. P. (1985). Safety in the laboratory. In Public Health Mycobacteriology. A Guide for the Level III Laboratory, pp. 510. US Department of Health and Human Services publication 868230. Atlanta, GA: Centers for Disease Control.

Kent, M. L., Whipps, C. M., Matthews, J. L., Florio, D., Watral, V., Bishop-Stewart, J. K., Poort, M. \& Bermudez, L. (2004). Mycobacteriosis in zebrafish (Danio rerio) research facilities. Comp Biochem Physiol C Toxicol Pharmacol 138, 383-390.

Kumar, S., Tamura, K. \& Nei, M. (2004). MEGA3: integrated software for molecular evolutionary genetics analysis and sequence alignment. Brief Bioinform 5, 150-163.

Lansdell, W., Dixon, B., Smith, N. \& Benjamin, L. (1993). Isolation of several Mycobacterium species from fish. J Aquat Anim Health 5, 7376.

Lebrun, L., Weill, F.-X., Lafendi, L., Houriez, F., Casanova, F., Gutierrez, M. C., Ingrand, D., Lagrange, P., Vincent, V. \& Herrmann, J. L. (2005). Use of the INNO-LiPA-MYCOBACTERIA assay (version 2) for identification of Mycobacterium aviumMycobacterium intracellulare-Mycobacterium scrofulaceum complex isolates. J Clin Microbiol 43, 2567-2574.

Lee, H., Bang, H. E., Bai, G. H. \& Cho, S. N. (2003). Novel polymorphic region of the rpoB gene containing Mycobacterium species-specific sequences and its use in identification of Mycobacteria. J Clin Microbiol 41, 2213-2218.

Levi, M. H., Bartell, J., Gandolfo, L., Smole, S. C., Costa, S. F., Weiss, L. M., Johnson, L. K., Osterhout, G. \& Herbst, L. H. (2003). Characterization of Mycobacterium montefiorense sp. nov., a novel pathogenic Mycobacterium from moray eels that is related to Mycobacterium triplex. J Clin Microbiol 41, 2147-2152.

Meier, A., Kirschner, P., Schröder, K. H., Wolters, J., Kroppenstedt, R. M. \& Böttger, E. C. (1993). Mycobacterium intermedium sp. nov. Int J Syst Bacteriol 43, 204-209.

Pate, M., Jencic, V., Zolnir-Dovc, M. \& Ocepek, M. (2005). Detection of mycobacteria in aquarium fish in Slovenia by culture and molecular methods. Dis Aquat Organ 64, 29-35.
Poort, M. J., Whipps, C. M., Watral, V. G., Font, W. F. \& Kent, M. L. (2006). Molecular characterization of a Mycobacterium species in non-native poeciliids in Hawaii using DNA sequences. J Fish Dis 29, 181-185.

Rhodes, M. W., Kator, H., Kotob, S., van Berkum, P., Kaattari, I., Vogelbein, W., Quinn, F., Floyd, M. M., Butler, W. R. \& Ottinger, C. A. (2003). Mycobacterium shottsii sp. nov., a slowly growing species isolated from Chesapeake Bay striped bass (Morone saxatilis). Int J Syst Evol Microbiol 53, 421-424.

Rhodes, M. W., Kator, H., Kaattari, I., Gauthier, D., Vogelbein, W. \& Ottinger, C. A. (2004). Isolation and characterization of mycobacteria from striped bass Morone saxatilis from the Chesapeake Bay. Dis Aquat Organ 61, 41-51.

Rhodes, M. W., Kator, H., McNabb, A., Deshayes, C., Reyrat, J. M., Brown-Elliott, B. A., Wallace, R., Jr, Trott, K. A., Parker, J. M. \& other authors (2005). Mycobacterium pseudoshottsii sp. nov., a slowly growing chromogenic species isolated from Chesapeake Bay striped bass (Morone saxatilis). Int J Syst Evol Microbiol 55, 1139-1147.

Ringuet, H., Akoua-Koffi, C., Honore, S., Varnerot, A., Vincent, V., Berche, P., Gaillard, J. L. \& Pierre-Audigier, C. (1999). hsp65 sequencing for identification of rapidly growing mycobacteria. $J$ Clin Microbiol 37, 852-857.

Roth, A., Reischl, U., Streubel, A., Naumann, L., Kroppenstedt, R. M., Habicht, M., Fischer, M. \& Mauch, H. (2000). Novel diagnostic algorithm for identification of mycobacteria using genus-specific amplification of the 16S-23S rRNA gene spacer and restriction endonucleases. J Clin Microbiol 38, 1094-1104.

Sakai, M., Kono, T., Tassakka, A. C. M. A. R., Ponpornpisit, A., Areechon, N., Katagiri, T., Yoshida, T. \& Endo, M. (2005). Characterization of a Mycobacterium sp. isolated from guppy Poecilia reticulata, using $16 \mathrm{~S}$ ribosomal RNA and its internal transcribed spacer sequences. Bull Eur Assoc Fish Pathol 25, 64-69.

Selvarangan, R., Wu, W. K., Nguyen, T. T., Carlson, L. D. C., Wallis, C. K., Stiglich, S. K., Chen, Y. C., Jost, K. C., Jr, Prentice, J. L. \& other authors (2004). Characterization of a novel group of mycobacteria and proposal of Mycobacterium sherrisii sp. nov. J Clin Microbiol 42, 52-59.

Short, W. R., Emery, C., Bhandary, M. \& O’Donnell, J. A. (2005). Misidentification of Mycobacterium peregrinum, the causal organism of a case of bacteremia and automatic implantable cardioverter defibrillator-associated infection, due to its unusual acid-fast staining characteristics. J Clin Microbiol 43, 2015-2017.

Springer, B., Kirschner, P., Rost-Meyer, G., Schröder, K. H., Kroppenstedt, R. M. \& Böttger, E. C. (1993). Mycobacterium interjectum, a new species isolated from a patient with chronic lymphadenitis. J Clin Microbiol 31, 3083-3089.

Springer, B., Stockman, L., Teschner, K., Roberts, G. D. \& Böttger, E. C. (1996a). Two-laboratory collaborative study on identification of mycobacteria: molecular versus phenotypic methods. J Clin Microbiol 34, 296-303.

Springer, B., Wu, W. K., Bodmer, T., Haase, G., Pfyffer, G. E., Kroppenstedt, R. M., Schröder, K. H., Emler, S., Kilburn, J. O. \& other authors (1996b). Isolation and characterization of a unique group of slowly growing mycobacteria: description of Mycobacterium lentiflavum sp. nov. J Clin Microbiol 34, 1100-1107.

Talaat, A. M., Reimschuessel, R. \& Trucksis, M. (1997). Identification of mycobacteria infecting fish to the species level using polymerase chain reaction and restriction enzyme analysis. Vet Microbiol 58, 229237.

Telenti, A., Marchesi, F., Balz, M., Bally, F., Böttger, E. C. \& Bodmer, T. (1993). Rapid identification of mycobacteria to the species level by polymerase chain reaction and restriction enzyme analysis. J Clin Microbiol 31, 175-178. 
Torkko, P., Suomalainen, S., livanainen, E., Tortoli, E., Suutari, M., Seppänen, J., Paulin, L. \& Katila, M. L. (2002). Mycobacterium palustre sp. nov., a potentially pathogenic, slowly growing mycobacterium isolated from clinical and veterinary specimens and from Finnish stream waters. Int J Syst Evol Microbiol 52, 1519-1525.

Tortoli, E. (2003). Impact of genotypic studies on mycobacterial taxonomy: the new mycobacteria of the 1990s. Clin Microbiol Rev 16, 319-354.

Tortoli, E. (2006). The new mycobacteria: an update. FEMS Immunol Med Microbiol 48, 159-178.

Tortoli, E., Mariottini, A. \& Mazzarelli, G. (2003). Evaluation of INNOLiPA MYCOBACTERIA v2: improved reverse hybridization multiple DNA probe assay for mycobacterial identification. J Clin Microbiol 41, 4418-4420.

Tortoli, E., Rindi, L., Goh, K. S., Katila, M. L., Mariottini, A., Mattei, R., Mazzarelli, G., Suomalainen, S., Torkko, P. \& Rastogi, N. (2005). Mycobacterium florentinum sp. nov., isolated from humans. Int J Syst Evol Microbiol 55, 1101-1106.

Turenne, C. Y., Cook, V. J., Burdz, T. V., Pauls, R. J., Thibert, L., Wolfe, J. N. \& Kabani, A. (2004a). Mycobacterium parascrofulaceum sp. nov., novel slowly growing, scotochromogenic clinical isolates related to Mycobacterium simiae. Int J Syst Evol Microbiol 54, 15431551.
Turenne, C. Y., Thibert, L., Williams, K., Burdz, T. V., Cook, V. J., Wolfe, J. N., Cockcroft, D. W. \& Kabani, A. (2004b). Mycobacterium saskatchewanense sp. nov., a novel slowly growing scotochromogenic species from human clinical isolates related to Mycobacterium interjectum and Accuprobe-positive for Mycobacterium avium complex. Int J Syst Evol Microbiol 54, 659-667.

Ucko, M., Colorni, A., Kvitt, H., Diamant, A., Zlotkin, A. \& Knibb, W. R. (2002). Strain variation in Mycobacterium marinum fish isolates. Appl Environ Microbiol 68, 5281-5287.

Weiszfeiler, J. G., Karasseva, V. \& Karczag, E. (1981). Mycobacterium simiae and related mycobacteria. Rev Infect Dis 3, 1040-1045.

Whipps, C. M., Watral, V. G. \& Kent, M. L. (2003). Characterization of a Mycobacterium sp. in rockfish, Sebastes alutus (Gilbert) and Sebastes reedi (Westrheim \& Tsuyuki), using rDNA sequences. J Fish Dis 26, 241-245.

Whipps, C. M., Butler, W. R., Pourahmad, F., Watral, V. G. \& Kent, M. L. (2007a). Molecular systematics support the revival of Mycobacterium salmoniphilum (ex Ross 1960) sp. nov., nom. rev., a species closely related to Mycobacterium chelonae. Int J Syst Evol Microbiol 57, 2525-2531.

Whipps, C. M., Dougan, S. T. \& Kent, M. L. (2007b). Mycobacterium haemophilum infections of zebrafish (Danio rerio) in research facilities. FEMS Microbiol Lett 270, 21-26. 